\title{
Wine Tourism as a Development Factor of the Primorska Wine Region
}

\author{
Simon KeRMA, Koper/Capodistria*
}

with 1 figure and 4 tables in the text

\section{Content}

Summary

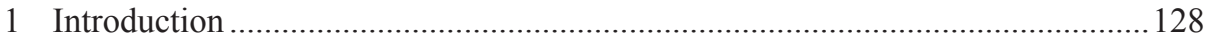

2 The Primorska wine region and its four wine districts....................................... 130

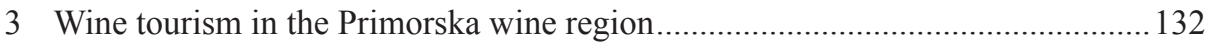

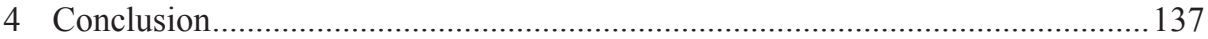

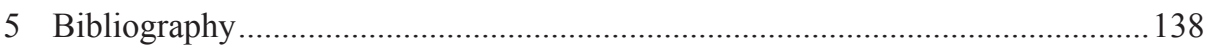

\section{Summary}

The paper deals with the Slovene wine region of Primorska and its four wine districts (the Brda Hills [Brda], the Vipava Valley [Vipava], the Karst Plateau [Kras] and Slovene Istria [Slovenska Istra]) in the context of wine tourism. The Primorska wine region (one of three in Slovenia) has developed a traditionally important viticulture, a relatively intensive production of typical grape varieties and in some cases also a distinct entrepreneurial spirit, which consequently reflects itself in the development of wine tourism and the region. Although in total characterised by the beneficial influence of the Mediterranean, Primorska is a relatively heterogeneous (wine) region. Its four wine districts could be defined as wine micro-regions with their own identities and

\footnotetext{
Simon Kerma, PhD. Candidate, Department of Geography, Faculty of Humanities, University of Primorska, Titov trg 5, SI-6000 Koper/Capodistria, Slovenia; e-mail: simon.kerma@fhs.upr.si
} 
more or less distinct conditions for wine growing. Comparative analysis reveals some major differences related to wine tourism offer and development strategies.

\section{Introduction}

"The great thing about wine tourism is that every wine region is a new experience waiting to happen, with its own wines, its own history, its own landscapes, and its own culture." (SOMMERs 2008, p. 259)

We can refer to one of many definitions and describe wine tourism as visiting vineyards, wineries, wine festivals and other wine events, with wine tasting and/or experiencing the attributes of a wine region being the dominant motivating factors for visitors (HALl et al. 2000). GETz \& BROwN (2006) consider wine tourism simultaneously - as a form of consumer behaviour, a strategy of local development and marketing local wines, especially by selling them directly to consumers. According to SHOR \& MANSFELD (2009), wine tourism is a type of special interest tourism conducted in wine districts where vineyards and wineries abound. TOMLJENOvić (2009) points out - in the context of wine tourism development in the Mediterranean space - that wine tourism is one of the more lucrative products and of extreme importance for many of the Mediterranean destinations.

Slovenia is an integral part of the Mediterranean geographical and cultural area with a long and rich viticultural tradition as well as well-developed tourism attractions. This is even more so with the Primorska region in the Southwest of the country.

Development of wine tourism in Slovenia has for almost 20 years (since 1992) been based on wine tourist routes in all three wine regions (Podravje, Posavje and Primorska) implemented by the Ministry of Agriculture, Forestry and Food. Despite this fact, wine tourism along wine routes, although considered an important feature for both tourism and wine producers, has received little attention by researchers - with some rare exceptions focusing on wine tourism marketing and brand name development (BOJNEC \& JURINČIČ 2006a, BOJNEC \& JURINČIČ 2006b), on the role of wine consortiums in wine marketing and wine tourism development (JURINČIČ \& BOJNEC 2006), marketing of wine tourism as a territorial product (BOJNEC, JuRINČIČ \& TOMLJENOVIĆ 2007), and some case studies of selected wine regions and districts (e.g. BoJneC, JuRinČIČ \& ToMlJENOvić 2006, JURINČIČ \& BOJNEC 2009).

The aim of this paper is to provide an analysis of the supply side of wine tourism in the Primorska wine region by highlighting each of its four wine districts. The Primorska wine region, in fact, is just a frame of its four wine districts, subregions or micro-regions, which have developed their own and recognized (in some cases also institutionally supported) identity ${ }^{1}$. A comparative perspective will be employed to

\footnotetext{
For regional identity see Anssi PAASI (2003).
} 
identify similarities and differences of strategies/approaches related to wine tourism development.

At first a brief description of the subregions is presented including some basic information on current viticulture. This is followed by the results of an analysis of selected elements of wine tourism supply and promotion, wine events and other activities including visits.

Figure 1: Primorska wine region in the Southwest of Slovenia

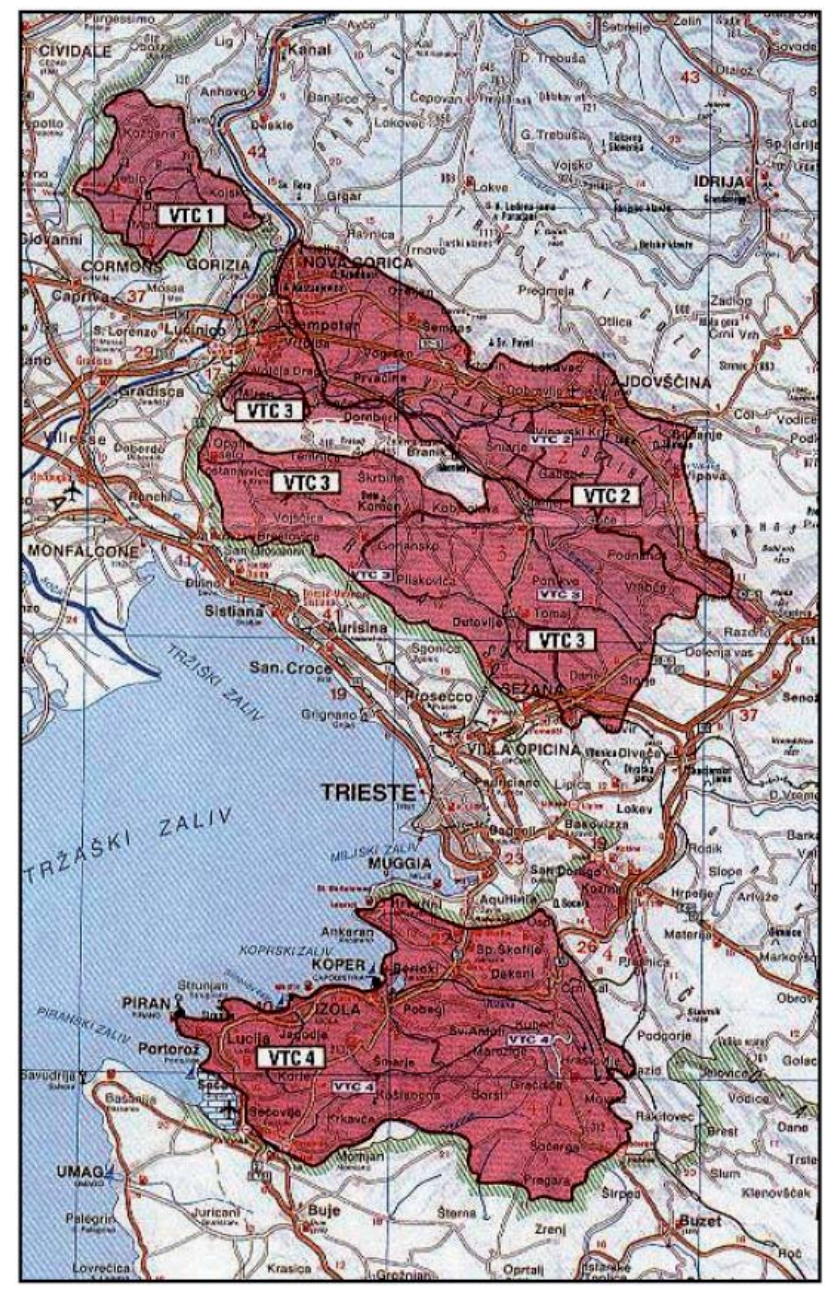

The four wine districts from North to South: Brda (VTC 1), Vipava (VTC 2), Kras (VTC 3), Slovenska Istra (VTC 4).

Source: Ministrstvo Za gospodarstvo Republike Slovenije, Direktorat Za turizem 2007 


\section{The Primorska wine region and its four wine districts}

The Primorska wine region is situated in the Southwest of Slovenia and includes the wine districts Brda Hills [Brda], Vipava Valley [Vipava], Karst Plateau [Kras] and Slovene Istria [Slovenska Istra]). The southern part of the region extends to the Adriatic Sea and the Istrian peninsula up to the border with Croatia. Towards the West it borders Italy, to the East and North it is limited by the harsh continental climate of higher hills and plateaus (see Figure 1).

According to Jancis RoBInSON (2006) Primorska has made great progress in wine quality since the early 1990s and is today the most appreciated Slovene wine region. The region is known for dry extract wines with a very complex structure and full taste. The Primorska wine region produces the majority of Slovenia's best reds.

In comparison to the other two (continental) wine regions of Slovenia, Primorska is in total characterised by the beneficial influence of the Mediterranean climate. It has lots of sunny days, is warm, in summertime also hot, but still with a considerable amount of precipitation. An occasional biting northeast wind (locally called burja) is also typical for the region, as well as mineral-rich soils. The influence of the sea can be felt in all parts of the region, but the mix of these general characteristics (with specific human responses to the environment) is different for each particular wine district. In fact, Primorska is quite a heterogeneous wine region. Its four wine districts could be defined as wine micro-regions with their own identities and more or less distinct conditions for wine growing. ${ }^{2}$

The Brda Hills in the Northwest at the border with Italy (VTC1 in Figure 1) are an area with approximately 6,000 inhabitants in one municipality and recognised as the most developed and esteemed wine district in the country. Soils consist mostly of marl, shale and sandstone in alternation (flysch). The Hills are very prone to erosion, so most of the vineyards must be terraced. They are best known for their matured red and white blends, but the local (regional) brand is definitely based on Rebula (Ribolla).

The Vipava Valley (VTC2 in Figure 1) is proud of its native wine specialities Zelen and Pinela. It is surrounded by higher karst plateaus. The climate is submediterranean to continental. There is enough rainfall and the soils are relatively rich, but this is the area most influenced by the cold and dry burja that sweeps down from the Northeast drying the soil and even eroding the top layer.

Kras (Carso in Italian, VTC3 in Figure 1) is unique in many aspects. Its typical karstic landscape made it the scientific term for similar land forms around the world. The relatively inhospitable surface with a lack of groundwater offers unfavouarble conditions for vegetation. The soil is terra rossa (jerina in Slovene), a characteristic red

2 The subdivision of the Slovene wine regions is based on ecological and physical-geographical factors important for growth and development of wine and influencing the character of wines (RAJHER 1997, ŠKVARČ \& BRDNIK 2011). 
earth, a product of limestone decay. The climate is harsh with frequent lasting droughts in summer and cold winters aggravated by burja, which dries the land. Terra rossa and burja are of fundamental importance for the production of the famous red wine Teran (Terrano) and the dried ham Pršut (Prosciutto).

Slovenska Istra (VTC4 in Figure 1), administratively composed of the three coastal municipalities of Koper/Capodistria, Izola/Isola and Piran/Pirano and a minor part of the municipality of Hrpelje-Kozina, is most distinctively influenced by the Mediterranean (the Adriatic Sea), though these influences slowly weaken towards the hilly hinterland of the area. However, the climate is mild, and the soils are mostly derived from flysch. The grapes of this area are the earliest to ripen of all the districts. Among wines the extremely popular Refošk (Refosco) and Malvazija (Malvasia) prevail. The later seems to be, surprisingly, one of the very rare common denominators for wine tourism promotion of the Primorska wine region.

In the Primorska wine region several (local and global) white and red grape varieties are cultivated. White varieties prevail in the Brda Hills and the Vipava Valley, whereas the red represent more than $50 \%$ in Kras and Slovenska Istra. Vintagers from Primorska mostly produce varietal wines, although some white cuvees are typical as well (Š́KVARČ \& BRDNIK 2011).

Table 1: Selected data for viticulture in Slovenia, Primorska and its wine districts, 2009

\begin{tabular}{|l|r|r|r|r|}
\hline $\begin{array}{c}\text { Country, region } \\
\text { and districts }\end{array}$ & $\begin{array}{c}\text { Number of } \\
\text { wine-growers }\end{array}$ & $\begin{array}{c}\text { Vineyards, } \\
\text { total size (ha) }\end{array}$ & $\begin{array}{c}\text { Grape production } \\
\text { (in 1,000 kg) }\end{array}$ & $\begin{array}{c}\text { Wine production } \\
\text { (in 1,000 l) }\end{array}$ \\
\hline Slovenia & 27,890 & 16,590 & 79,263 & 54,833 \\
\hline Primorska & 4,604 & 6,718 & 41,236 & 28,418 \\
\hline Brda & 834 & 1,906 & 13,677 & 9,540 \\
\hline Vipava & 1,781 & 2,437 & 14,410 & 9,922 \\
\hline Kras & 898 & 635 & 3,418 & 2,448 \\
\hline Slovenska Istra & 1,091 & 1,740 & 9,730 & 6,509 \\
\hline
\end{tabular}

Source: Ministrstvo za kmetiJstvo, gOZdarstvo in PRehrano Republike SLoveniJe, Agricultural INSTITUTE OF SLOVENIA 2010

According to official data of registered grape and wine production, Primorska obviously dominates among the three wine regions in Slovenia. Only one sixth of all Slovene vintagers are from Primorska, but they cultivate $40 \%$ of the total area of vineyards and provide $52 \%$ of the total grape and wine production in the country (see Table 1). Table 1 also shows that the most productive wine district is Brda, where the structure of holdings is the most favourable among the four wine districts. 


\section{Wine tourism in the Primorska wine region}

We proceed now to wine tourism in the broader context of regional development in each of the four wine districts of Primorska. We are therefore interested in the touristic offer of wine tourist routes, traditional wine-related festivals and events that (wine) tourists can visit and the actual number of visitors recorded as well as visits to the four largest wine cellars in the region. In the context of district promotion, we take into account the role of different players (tourist information centres, wine associations and consortia, individual vintagers, etc.). For this purpose we conducted some structured interviews with competent representatives to get relevant information.

It is evident that in Slovenian development plans wine tourism (still) does not occupy the position that it probably deserves, although most of the documents stress its potential for local or regional development. The authors of the "Development Plan and Policies of Slovene Tourism", e.g., conceive wine tourist routes, an already developed segment of tourism, as one of the key elements of an authentic tourist offer, that should, however, be more intensively integrated into an integral tourist product of the tourist destinations (URAN \& OvSENIK 2006).

No more specific suggestions can be found in the Regional Development Programme of South Primorska 2007-13 (RDA South PRIMORSKA 2006), which is rather general and proposes only a clustering of supply with markets by promoting the wine route offer.

The Regional Development Programme (RDP) of North Primorska 2007-13 (RDA NoRTH PRIMORSKA 2006b) is much more specific, when it stresses the big potential of wine tourism, especially in connection with excellence in tourism (Priority 2) and the promotion of sustainable tourism development, with two bigger projects planned (the museum of wine culture in the Brda Hills and the reconstruction of an old wine cellar in Vipava in connection with the establishment of the museum of winegrowing of Slovenia).

The development of wine tourism is by all means directly connected to rural development. Even though the cover document of the Republic of Slovenia's Rural Development Programme 2007-13 (Ministrstvo Za KMEtisstvo, GOzDarstvo IN PREHRANo Republike SloveniJe 2007) disregards wine tourism completely, its importance is recognized in all local or regional strategies (rural development programmes), which include the areas of the wine districts analysed (RDA NORTH Primorska 2006a, RDC Koper 2008, ROD AJdovščInA 2008, TDC KRAS AND BRKINI 2008). All these documents stress the importance of enhancing viticulture and wineproducing farms together with the development of complementary tourism supply along wine tourist routes. 


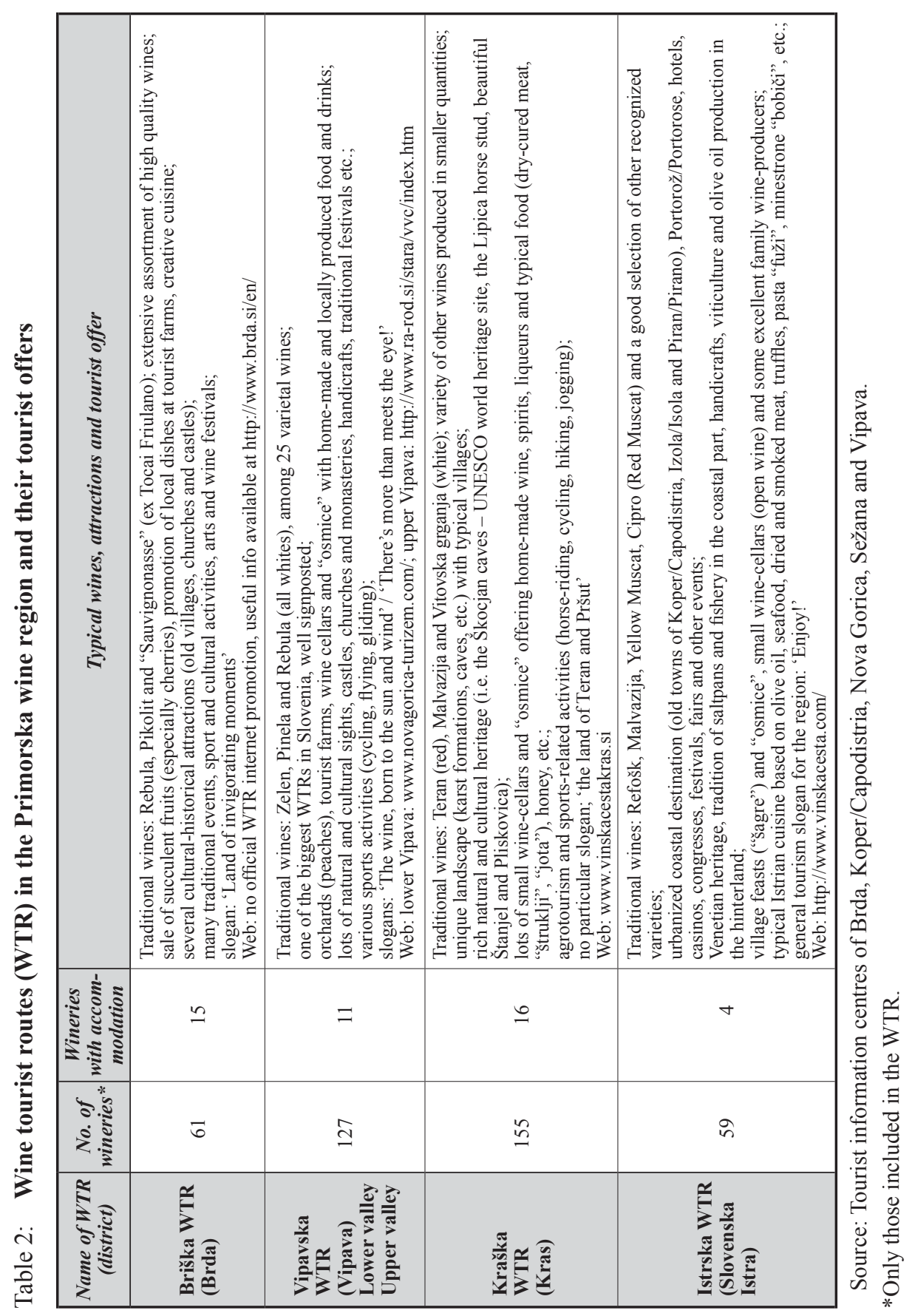


Surprisingly, the Briška WTR (Brda) is not on the web. It is, however, signposted in the field (as others). Its offer includes the most (due to the size of the district) and best (with vintagers) accommodation facilities. It is very homogenous (a single municipality!) offering a wide range of tourist attractions, events and activities. Wine is part of every event, but the Cherry Festival is the best known and visited of all.

The Vipavska WTR (Vipava) is divided into the Lower and the Upper Vipava Valley, which causes coordination problems between the tourist information centres of the two parts. They have their own specifics, e.g., Zelen and Pinela are more characteristic for the Upper Vipava Valley. But the tourist offer improves continually, although accommodation offered by vintagers is still too scarce. A very positive factor that could help strengthen wine tourism is the School of Viticulture and Enology in Ajdovščina (as a part of the University of Nova Gorica).

The Kraška WTR (Kras) is perhaps advertised best - by an up-to-date web page and catalogues. The offer is really diverse; practically every vintager, also those producing nothing more than house (open) wine, participates. Very important is the authentic local enogastronomic offer, which is both traditional ("osmice") and innovative (e.g. Terra Carsus, the Slovene-Italian project of young chefs).

Istrska WTR (Slovenska Istra) has despite its undeniable potential fallen behind in development and upgrading its offer, which is based on typical Istrian wines, olive oil and cuisine together with its characteristic Mediterranean landscape. The biggest problem is a non-defined status of trustees and consequently uncoordinated management of the three coastal municipalities. The district's webpage is out of date, but the major problem is, that there are virtually no accommodation facilities in the countryside with vintagers and other farmers.

The authors of local and regional rural development plans share the opinion that WTRs represent the backbone of rural development, but need to be upgraded by authentic events and festivals. They consider it extremely important to establish a regular control system of suppliers, which due to the non-defined status of trustees still doesn't work as it should.

It has, however, also to be said that many suppliers are rather passive when it comes to participating, e.g., in seminars focusing on the improvement of the tourist offer. Local authorities and tourist organizations as well as vintagers' associations are to motivate suppliers by awarding them, offering advice as regards maintenance of buildings and outdoor areas as well as trade mark design and offering administrative support with tenders for development funds, etc. This seems all the more necessary, since for most vintagers wine growing is not the main activity, but merely adds to the family income.

Authorities are also to feel responsible for the promotion of WTRs, to provide tourist offices and agencies with up-to-date information on the tourist offer. It is also vital to combine the WTR offer with other forms of the tourist offer in the countryside, 


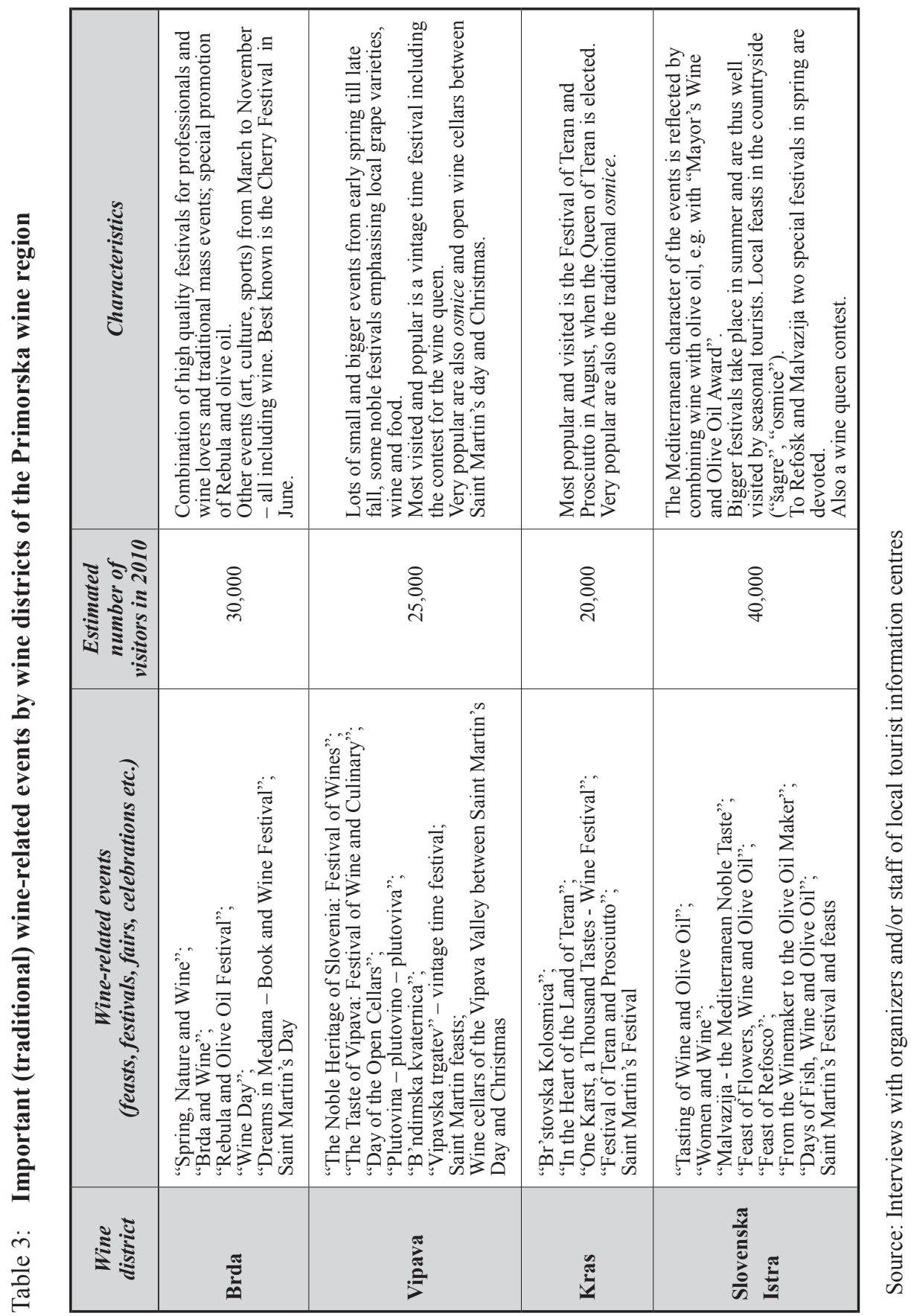


e.g., by organizing daytrips or longer travel packages. At the moment, only some local tourist agencies are independently developing and marketing the big potential of WTRs.

Traditional events related to wine are an important part of a quality tourism offer in the region. As can be seen in Table 3, this offer is quite diversified and locally specific, yet in some aspects quite similar, since it is based on similar traditions and customs (grape-harvesting, festivities on Saint Martin's Day, established promotional strategies like open cellars, wine queens, etc.).

While data on visits to all (or the majority of) wine cellars are not available, we have collected data on the biggest four wine cellars in the Primorska wine region (one for each wine district).

Table 4: Visits to the four biggest wineries in the Primorska wine region in 2010

\begin{tabular}{|l|l|c|c|l|}
\hline \multicolumn{1}{|c|}{ Wine district } & \multicolumn{1}{|c|}{ Winery } & $\begin{array}{c}\text { Number of } \\
\text { visitors* }\end{array}$ & $\begin{array}{c}\text { Percentage of } \\
\text { foreign visitors }\end{array}$ & $\begin{array}{c}\text { Country of } \\
\text { origin** }\end{array}$ \\
\hline Brda & $\begin{array}{l}\text { Goriška Brda } \\
\text { Wine Cellar }\end{array}$ & 12,000 & 25 & $\begin{array}{l}\text { UK, Italy, } \\
\text { Belgium }\end{array}$ \\
\hline Vipava & Vipava 1894 & 1,500 & 35 & $\begin{array}{l}\text { Italy, Austria, } \\
\text { Germany }\end{array}$ \\
\hline Kras & Vinakras & 2,500 & 35 & $\begin{array}{l}\text { Austria, } \\
\text { Germany, Italy }\end{array}$ \\
\hline Slovenska Istra & Vinakoper & 10,000 & 47 & $\begin{array}{l}\text { Germany, } \\
\text { Austria, Italy }\end{array}$ \\
\hline
\end{tabular}

*Approximate number of visitors with guided tours and wine-tastings;

**Countries in the order of visitor numbers

Source: Interviews with the staff of each winery

As can be seen from Table 4, the Goriška Brda Wine Cellar and Vinakoper stand out by tourist visits. These two wineries are among the biggest in Slovenia, according to production and recognition. In the past few years they have both been investing a lot into the promotion of their trademarks, by skilfully incorporating the typical elements of regional identity.

While Vinakras, in size quite smaller than the previous two, receives the expected number of visitors, this is most certainly not true for Vipava 1894, which is a winery of the same category as Goriška Brda Wine Cellar and Vinakoper. According to the management, the number of visitors constantly declined in recent years. Reasons are the new motorway making it easy to bypass Vipava and to proceed to Nova Gorica and 
Brda, the termination of the Vipava 1894-Postojna Cave connection, but most of all the serious lack of promotion of the winery as an integral part of the Vipava Valley tourist destination.

\section{Conclusion}

To summarize the main results of this preliminary study (to be followed by in-depth research), we can describe the Primorska wine region as versatile and heterogeneous on the one hand and internally poorly connected and uncoordinated on the other. One of the reasons for the latter is the fact that Primorska is not an administrative unit (due to the lack of administrative units at the regional level in Slovenia) and also statistically and in development plans divided into Southern and Northern Primorska. The Primorska wine region differs significantly from the other two Slovenian wine regions (Podravje and Posavje) due to its Mediterranean character, which positions it much closer to the neighbouring Friulian wine regions DOC Collio, DOC Friuli Isonzo and DOC Carso.

The heterogeneity of the Primorska wine region expresses itself also in its four wine districts (Brda, Vipava, Kras and Slovenska Istra). Despite being situated in close neighbourhood, they are quite distinct and have their own identities based on specific microclimatic, relief and pedologic conditions, on history and specific human responses to the environment. This distinctness is reflected by the conditions for wine growing and the characteristic grape and wine varieties, but also by different kinds of wine-tourism. But even the districts are all but homogeneous, especially the Vipava Valley with its lower and upper sections, mainly due to administrative fragmentation into several municipalities.

The Brda wine district belonging entirely to one municipality has an advantage in this respect and is also the most developed Slovene wine region. This reflects itself also in wine tourism. According to JURINČIČ \& BOJNEC (2009) we can classify Brda as belonging to the third (maturity) stage of the wine tourism destination life-cycle, whereas the other three wine districts still correspond to the second (developing) stage.

Wine tourist routes are an important element of wine tourism development (or rural development in general) in all wine districts of the Primorska wine region. However, there are still some shortcomings that limit greater efficiency. Yet we witness a high quality tourist offer in these wine districts, especially in connection with traditional (and some innovative) wine-related events. The offer is diversified and locally specific, yet in some aspects quite similar, since it is based on similar traditions and customs.

Wine festivals and events are in general well visited. The majority of visitors, however, especially of traditional events, are locals and daily visitors rather than (wine) tourists. An exception is to some extent Slovenska Istra, where the higher number of visitors is the result of summer tourism, which is also reflected by the higher number of 
foreign visitors to the Vinakoper winery. According to some organizers, there are even too many wine-connected events and competition for visitors is strong. But certainly, only original and authentic events will prosper also in the future.

It will anyway be necessary to carry on in-depth research on motives and impressions of tourists visiting the Primorska wine region.

\section{Bibliography}

BOJNEC Š., JURINČIČ I. (2006a), Marketing and brand name development: wine and wine tourism. In: Podnar K., JANČIČ Z. (eds.), Contemporary Issues in Corporate and Marketing Communications: Towards a Socially Responsible Future, pp. 252-254. Ljubljana, Fakulteta za družbene vede.

BoJNEC Š., JURINČIČ I. (2006b), Wine regions, brand name, and wine tourism marketing: the Slovene Istria. In: Tsartas P., Christou E., Sigala M. (eds.), In search of excellence for tomorrow's tourism travel and hospitality: proceedings, pp. 25-28. Thessaloniki, The University of the Aegean.

BoJNEC Š., JuRINČIČ I., TomLJENOvić R. (2006), Wine growing areas and wine tourism in Slovenia and Croatia. In: Faculty of Tourism and Hotel Management (ed.), Tourism \& hospitality industry 2006: new trends in tourism and hospitality management: congress proceedings: $18^{\text {th }}$ Biennial International Congress, May 03-05, 2006, pp. 588-604. Opatija, Faculty of Tourism and Hotel Management.

BoJNEC Š., JURINČIČ I., TOMLJENOVIĆ R. (2007), Marketing of wine tourism as a territorial product. In: BoJNEC Š. (ed.), Managing global transitions: globalisation, localisation, regionalisation (International Management Conference), pp. 1075-1082. Koper, Faculty of Management.

Getz D., Brown G. (2006), Critical success factors for wine tourism regions: a demand analysis. In: Tourism Management, 27, pp. 146-158.

Hall C.M., Sharples L., Cambourne B., Macionis N. (2000), Wine Tourism around the World. Butterworth, Heinemann.

JURINČIČ I., BOJNEC Š S. (2006), The role of wine consortiums in wine marketing and wine tourism development in Slovenia. In: Mulej M., Rebernik M., Krošlin T. (eds.), STIQE 2006: proceedings of the 8th International Conference on Linking Systems Thinking, Innovation, Quality, Entrepreneurship, and Environment, Maribor, Slovenia, 28-30 June, 2006, pp. 81-86. Maribor, Faculty of Economics and Business, Institute for Entrepreneurship and Small Business Management.

JURINČIČ I., BOJNEC Š (2009), Wine tourism development: The case of wine district in Slovenia. In: Tourism, 57, 4, pp. 435-448.

Ministrstvo za gospodarstvo Republike Slovenije, Direktorat za turizem (ed.) (2007), Strategija razvoja zidaniškega turizma. Ljubljana.

Ministrstvo za Kmetisstvo, gozdarstvo in prehrano Republike Slovenije (ed.) (2007), Program razvoja podeželja Republike Slovenije za obdobje 2007-2013. Ljubljana.

Ministrstvo za kmetijstvo, gozdarstvo in prehrano Republike Slovenije, Agricultural institute of Slovenia (eds.) (2010), Poročilo o stanju kmetijstva, živilstva in gozdarstva v letu 2009. Pregled po kmetijskih trgih. Kmetijski inštitut Slovenije. Ljubljana. 
PAasi A. (2003), Region and place: regional identity in question. In: Progress in Human Geography, 27, 4, pp. 475-485.

RAJHer Z. (1994), Korenine slovenskega vinogradništva. In: PrunK J. et al. (eds.), Vodnik po slovenskih vinorodnih okoliših, pp. 10-22. Ljubljana, Založba Grad.

Robinson J. (2006), The Oxford companion to wine. Oxford, Oxford University Press.

RDA North Primorska (ed.) (2006a), Razvojni program podeželja občin Šempeter - Vrtojba, Brda in Miren - Kostanjevica 2007-2013. Regional Development Agency of North Primorska. http://www.sempeter-vrtojba.si/?vie=gds\&id=20081002123 608 (15.2.2011).

RDA North Primorska (ed.) (2006b), Regionalni razvojni program Severne Primorske 20072013. Regional Development Agency of North Primorska. http://www.prc.si/dokumenti (15.2.2011).

RDA South Primorska (ed.) (2006), Regionalni razvojni program Južne Primorske 2007-2013. Strateški in izvedbeni del programa. Regional Development Agency of South Primorska. http://www.rrc-kp.si/programi/76 (15.2.2011).

RDC Koper (ed.) (2008), Lokalna razvojna strategija za območje občin Koper, Izola in Piran. Regional Development Centre Koper. http://www.las-istre.si/akti-in-dokumenti (15.2.2011).

ROD AJDovščINA (ed.) (2008), Lokalna razvojna strategija za območje Zgornje Vipavske doline in Komenskega Krasa (občine: Ajdovščina, Komen in Vipava) za programsko razvojno obdobje 2007-2013. ROD Development Agency. http://www.las-razvojpodezelja.si/ (15.2.2011).

Shor N., Mansfeld Y. (2009), Between wine consumption and wine tourism: Consumer and spatial behaviour of Israeli wine tourists. In: Tourism, 57, 4, pp. 381-403.

Sommers B.J. (2008), The geography of wine: how landscapes, cultures, terroir, and the weather make a good drop. New York, Plume.

ŠKVARČ A., BRDNIK M. (2011), Vinorodna dežela Primorska. Kmetijsko gozdarski zavod Nova Gorica. http://www.kvz-ng.si/panoge/vinogradnistvo (10.2.2011).

TDA KRAS AND BRKINI (ed.) (2008), Razvojni program podeželja Krasa in Brkinov za območje občin Divača, Hrpelje-Kozina in Sežana za obdobje 2007-2013. Territorial Development Agency of Kras and Brkini. http://www.ora.si/las.php (15.2.2011).

Tomljenović R. (ed.) (2009), Wine tourism in Mediterranean. In: Tourism, 57, 4, pp. 361-500.

Uran M., Ovsenik R. (2006), Development plan and policies of Slovene tourism 2007-2011. Ljubljana, Ministry of the Economy. 
